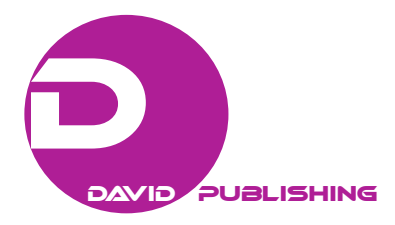

\title{
South Africa's Media Freedom Landscape and the Closures in Democracy
}

\author{
Glenda Daniels \\ University of Witwatersrand, Johannesburg, South Africa
}

\begin{abstract}
This research uses a theoretical conceptual method based on Chantal Mouffe's Radical Democracy which blended with Derrida's deconstruction thesis about "democracy to come" to reach findings on the state of South Africa's media freedom landscape. The method is contained in the conceptual framework. The article provides the constitutional legal landscape — or the overarching laws of the land — and the co-regulatory framework within which journalists work. There are four research explications: the Protection of State Information Bill (dubbed the Secrecy Bill), a painting of the president and Freedom of Expression, an arson attack on a community radio station and finally, the death of a photojournalist at the hands of police. The argument here is that the death, the arson attack, the Secrecy Bill, and the shut-down of dissent during the exhibition of the painting of the president all undermine democracy and signify significant closures for the media in the now 20-year-old post-apartheid South Africa. The analysis and reflections will be framed within theories of radical democracy, which argue for more fights and contestations and more voices from the margins in order to deepen democracy, rather than rational consensus which closes the spaces for greater plurality.
\end{abstract}

Keywords: radical democracy, media, freedom of expression, secrecy, closures, aporias

\section{Introduction}

In her radical democracy thesis vis-à-vis the media's role in a democracy, Chantal Mouffe (2006, p. 974) suggests that: "Ideally, the role of the media should precisely be to contribute to the creation of agonistic public spaces in which there is the possibility for dissensus to be expressed or alternatives to be put forward". This article goes beyond the formulation of the role of the media based on the normative "watchdog" theories ${ }^{1}$ in its examination of the South African media freedom landscape's 20 years into democracy. However, theoretically the author goes deeper into deploying radical democracy theories in an explication of significant aporias (gaps or puzzlements) of this transitional democracy in its treatment of the media. One of these gaps includes a dangerous (for journalists' and civil society broadly) impending law-the Protection of State Information Bill, dubbed the Secrecy Bill—which, if passed, will restrict the free flow of information via media to the public. "Secrecy obstructs democracy by keeping the public ignorant of information that it needs to make wise policy choices" (Johannsen, 1994).

This article is framed within two sets of non-competing political theories which will be explained in the next section. It will deploy concepts to explain and reach some analysis and reflections on the media freedom

Glenda Daniels, senior lecturer, Media Studies department, University of Witwatersrand.

1 See also Berger, G. (2002), Lardner, T. (1993), Jacobs, S. (2001). 
landscape. The methodological approach operationalizes concepts deployed in the theoretical framework. It is therefore a theoretical contribution, the aim of which is to understand the gaps, puzzlements, and contradictions in South Africa's 20-year-old democracy which has a progressive constitution on the one hand and significant closures and threats for media freedom on the other.

\section{Radical Democracy and Democracy to Come}

In their 1985 work Hegemony and Socialist Strategy, Ernesto Laclau and Chantal Mouffe (2001) argued that democracy is secured precisely through its resistance to realisation. They stated that the different political spaces and the plurality of such spaces are part and parcel of the deepening of a democratic order. Within this democratic order, there is a multiplicity of open spaces consisting of fights and contestations, changing meanings and constant flux. Difference and acceptance of difference, rather than hegemonic thought and unity of opinion, are therefore necessary in any democratic transition. Dissension should be accepted, and those who criticise should be viewed as legitimate adversaries - part of a democracy, occupying the same symbolic space, but with different views - rather than enemies. This is how a radical democracy is generated, according to Mouffe in her work The Democratic Paradox (2000).

Against this background, it must be noted that the South African media, although far from one united whole, professes to play a vital role in entrenching the articles of the Constitution by ensuring a transparent democracy which holds public officials accountable for their decisions and actions, and exposes the abuse of power and corruption by ruling elites. Rather it plays a watchdog role.

According to Mouffe (2006, p. 974), in a "radical pluralist democracy", the media can be more than "watchdogs"; they can be gate-openers rather than gate-closers. Her model of democracy not only allows for theorizing the increase of pluralism within journalism, but also allows for the increase of pluralism through journalism (Daniels, 2012). The more noise and contestations and the greater the fights, the better it is for the deepening of democracy, she argued in The Democratic Paradox (2000) and On the Political: Thinking in Action (2006).

Mouffe (1999) argued for the importance of the plurality of political spaces and the multiplicity of voices in the public sphere. One way to understand radical democracy is through its aims (Daniels, 2012) to create a deeper and more expansive democracy than that, which is currently on the table in the Western world. Radical democracy emerged in response to the crisis that affected the Western left wing thought in the second half of the Twentieth Century. These crises included dissatisfaction and disillusionment with the Marxist project and the rise of social movements which, according to Little and Lloyd (2009), including feminist struggles, gay and lesbian issues, and environmental concerns, among other particular micro politics. However, according to Derrida (2004), this aspiration of complete equality or true democracy can never be fully realised; it is open-ended and conflictual by nature, always contested, and not open to final realisation or reconciliation.In other words, it is a "democracy to come". There is an overlap between Mouffe's radical democracy, which is conditional, and the deconstruction of Derrida's state of fluidity and lack of decidability. In this argument, the media occupies precisely one such space in South Africa — part of the pluralistic public sphere-where different views and spaces can be expressed and where dynamic deliberations and contestations can and do take place. The closing off of the open spaces for media would shut down the democracy to come.

The Derridean democracy is one that is never fully realised; it is constantly unfolding and "becoming", and its moment of realisation would then necessarily see its disintegration. In On the Political, Mouffe wrote 
that democracy is something uncertain and improbable and must never be taken for granted. Against this theorising borrowed from radical democracy (Mouffe) and deconstruction (Derrida), this article now turns to the democratic legislative framework for the media in South Africa to apply the theories. Following this, there will be an elucidation of the attempts at closures, the fights and contestations, the multiplicity of voices and difference through the Secrecy Bill (and the National Key Points Act), an arson attack on a community radio station and then the ultimate closure - the death of a photographer.

\section{The Free Country and the Unfree Country: Legally Speaking}

The supreme law that governs the country is The Constitution of South Africa, which provides for freedom of expression and the right to information. However, it also protects human dignity and does not allow hate speech or racism, among other undesirables in a progressive society. It contains important protections for media freedom. The right to freedom of expression is protected by the clauses in Section 16 (1). Everyone has the right to freedom of expression. This includes:

(1) freedom of the press and other media;

(2) freedom to receive or impart information or ideas;

(3) freedom of artistic creativity;

(4) academic freedom and freedom of scientific research.

However, no such right in the Constitution is absolute; other rights such as human dignity exist to balance the freedom of speech. The civil society freedom of expression watchdog body, the Freedom of Expression Institute (2008), pointed out that while media freedom is constitutionally protected and the country has one of the freest media in Africa, as the "honeymoon phase of our new democracy fades, so it becomes clear that attacks on media freedom are increasing". This has become evident with the trajectory of the Protection of State Information Bill (Secrecy Bill). ${ }^{2}$

\section{The Protection of State Information Bill}

The Protection of State Information Bill, which was first mooted in Parliament in 2008 to ostensibly protect national security, has received widespread attention in the past six years. The bill contradicts the right to information contained in the Promotion of Access to Information Act (Paia) of 2000, having a chilling effect on citizens' rights to information, as well as journalists' abilities to access information, be in possession of certain documents and impart information. While the aim of the bill was to repeal the apartheid era information/classification legislation of 1992, after several drafts and re-drafts, the amended bill which was re-introduced in Parliament in 2011 was passed by the majority of members in the National Assembly in 2012. It was passed without an adequate public interest defence clause: it did not protect whistleblowers and journalists from disclosing or being in possession of information which could be classified or state secret. At the time of writing in November 2014, the bill awaited the President's signature before it becomes law.

\section{Civil Society and the Media's Problems with the Secrecy Bill}

The R2K campaign (launched in 2010 as coalition of organisations as a direct result of antipathy towards

\footnotetext{
${ }^{2}$ In 2012, and as a direct result of the bill, Reporters without Borders downgraded South Africa's ranking by 10 notches in terms of freedom of information: It went from $42 \mathrm{nd}$ in the world to 52nd. The reason cited was that the bill would threaten investigative journalism.
} 
the bill), the Congress of South African Trade Unions (Cosatu), the official opposition party, the Democratic Alliance, Print and Digital Media South Africa, and the South African National Editors' Forum (Sanef) are among some of the bodies opposed to the bill and they intend challenging it in the Constitutional Court. The bodies made various interventions in Parliament for amendments and they were successful, for instance, with acquiring the limited public interest defence. The organisations opposed to the bill, even in its amended form, ${ }^{3}$ argue that it still impedes the free flow of information stipulated in the Constitution via the Promotion of Access to Information Act (Paia) of the year 2000. The bill, if passed into law, could create a society of secrets and result in self-censorship for journalists, discourage whistle-blowers from passing on damning and indicting information and, most of all, hinder the public's right to information. There are jail terms for journalists and whistleblowers - signifiers of closures in a democracy.

\section{The Closures in a Democracy of the Secrecy Bill}

The parameters of what constitutes the national interest have not been narrowed down enough and the now partial limited interest defence still criminalizes some activity of investigative journalism.

There are still wide-ranging powers given to the security cluster/agency, which could slant the country towards a security state.

The classifier of information may classify categories of documents without interrogating whether each specific document poses a threat to national security or not. This is exacerbated by the fact that, according to media rights lawyer, Dario Milo, there is no imperative in the bill for a classifier to sever from a document the material which does not harm national security and make that available. "These twin flaws may well result in over-classification and hence censorship". 4

There are jail sentences of between 15 and 25 years for espionage. Journalists and whistleblowers could fall into this bracket.

\section{The National Key Points Act}

The National Key Points Act — because the "national interest" is invoked again—is an anachronistic piece of legislation; namely, remaining on the statute books since apartheid days. According to information rights activists such as Right2Know, and investigative journalist organisations such as amaBhungane, this legislation, which disallows journalists from taking photographs of "certain national key points", should be reviewed. However, the act, in its current and unamended form, prevents publication of security arrangements at strategic installation points called national key points. According to Right2Know, there are about 182 national key points but there is no clarity on what they are and they are campaigning for a transparent list. National key points may include: banks, munitions industries, petro-chemicals; water, air, and electricity industries, and also data processing, research and technology information systems. The law prevents journalists and photographers from reporting about and taking pictures of any state department or public entity. The problem for activists and journalists here is that the key points are not identified and the Minister of Safety and Security could, for example, declare any building a key point. This happened in 2012 when President Jacob Zuma's R260-million Nkandla homestead was improved and modernised, allegedly with taxpayers' money. The Nkandla homestead,

\footnotetext{
3 Mail \& Guardian 28 November 2012, Concourt action will be Secrecy Bill activists' last resort: http://mg.co.za/article/2012-11-28-00-info-bill-will-go-to-concourt-say-experts 4 Milo, D. (2013). Protection of State Information bill: Looser Muzzle Leader.co.za
} http://www.leader.co.za/article.aspx?s=6\&f=1\&a=4484: 18 May 2013 
built for the president with state money, was declared a national key point. The National Key Points Act, together with the Secrecy Bill, adds to the creation of a secret state, a lack of accountability, and a lack of clarity about what constitutes an offence.

\section{Analysis: Closures in Opposition to the Deepening Democracy}

The National Key Points Act and the Secrecy Bill treat the media and civil society as "outsiders" to the democracy; as enemies, to so to speak. However, enemies do not share a common symbolic space, whereas friends do (Mouffe, 2005). In this case, the media and civil society argue for more transparency and accountability through the free flow of information, which would deepen democracy rather than impede it. Mouffe, in explaining Derrida's theses on the Politics of Friendship and "Democracy to come", stated that we must accept difference and agonistic differences, rather than treat those with different views as enemies (jailing journalists and whistleblowers would be the ultimate in "othering" or making an enemy of players in a democracy). Treating others (who clearly share symbolic spaces but with different views and voices) as legitimate adversaries rather than enemieswould instead constitute the support and development of pluralism in society, deepening democracy in the process. The rational consensus dream of total mastery over everything (in this case, the Secrecy Bill as the weapon or master of closure) must be given up. Instead, democracy should be viewed as process encompassing agonism and difference. The next section will discuss a further possible closure: a resolution of the ruling party, the African National Congress (ANC) for a Media Appeals Tribunal.

\section{Media Appeals Tribunal (MAT): From Self-regulation to Independent Co-regulation— to a Parliament MAT}

Since the start of democracy in 1994, South Africa's press has been governed through self-regulation. Due to pressure by the ruling party, the ANC, the press decided to re-examine its governing system. In 2012 the press appointed the Press Freedom Commission (PFC) to conduct public hearings, do research on best practice around the world, and advise on an appropriate system of governance/accountability system for the press.

The press regulatory system changed from self-regulation to "independent co-regulation", 5 when in essence, the PFC recommended an increase in public representation and a few new positions. However, the internationally accepted understanding of "co-regulation" means joint regulation with the government. In South Africa, this was clearly not the case. The public and members of the press govern the press.

The decision the PFC reached, which was accepted by the industry, came after a series of public hearings involving, for example, members of the ANC, South African Communist Party (SACP), individuals, representatives from non-governmental organisations (NGOs) editors, and academics. In addition, research was conducted in Tanzania, India, the United Kingdom, and Denmark.

As already stated, the media conducted this process because it was under "pressure": It was wary of the ANC's proposal for a Media Appeals Tribunal (MAT), made at its national policy conference in December 2007. It is not completely clear what a MAT means, but it does mean that regulation of the press would ultimately lie in the hands of parliament, the majority of whose members belong to the ruling party, the ANC.

Despite this change to co-regulation, the ANC still held onto the idea of a MAT in a resolution, first

\footnotetext{
${ }^{5}$ Press Council 9 October, 2012, South Africa's Press-a new start for old values A revamped Press Council, http://www.presscouncil.org.za/News/View/south-africas-press--a-new-start-for-old-values-72
} 
mooted at Polokwane in, 2007, and again at Mangaung in 2012. ${ }^{6}$ At the ANC's last policy conference in 2012, it resolved that there was a need "for Parliament to conduct an inquiry on the desirability and feasibility of a MAT within the framework of the country's Constitution that is empowered to impose sanctions without the loss of any constitutional rights". ${ }^{7}$ However, in all fairness, while the MAT remains a resolution there has been no sign of active pursuit in 2014. Nonetheless, the ANC appears to be committed to gaining some form of political control of the media, but it does not seem to be clear on how to implement this. At the time of writing - the end of 2014 - all was quiet from the ANC about the MAT but it is a threat to democracy because of the freedoms it would curtail.

\section{Analysis: Closure in a Democracy}

If a MAT was instituted, freedom and independence of the press would be lost. Journalists would probably be required to register and acquire "licences". Who would then decide whether a journalist could practice or not? Journalists would probably self-censor for fear of being hauled in front of parliament for particular stories that he or she had written which could be considered to be embarrassing for the government, the president or the ANC. The aim of the ANC is to create a society with more consensuses, rather than to accept the society which exists at present - one that is full of fights and contestations - where corruption scandals are laid bare on the front pages of the newspapers. In the theory of Derrida, this is a democracy that is becoming and unfolding. In the theory of Mouffe, a MAT would hinder and impede the noise of the democracy that is currently unfolding. A MAT would close down the space of the multiplicity of voices, the plurality that is struggling to find itself in the public sphere through media and in other ways; for example, protests over service delivery and the Secrecy Bill. Through its desire for a MAT, the ANC clearly wants a society in which it could hegemonize further by closing down the open spaces. If journalists had to register to acquire licences and the ruling party decided who could and who could not get a licence, critical voices in the media would be lost.

The closing down of co-regulation and the replacement with a MAT would constitute cutting down plurality, diversity, fights, and contestations. This resolution suggests that the ANC perceives the media as the enemy, as "other" and as outsiders, rather than legitimate adversaries, sharing a common symbolic space. It desires the press to be at one with it and on its side, rather than accepting difference and accepting journalists as necessary adversaries in a democracy.

\section{Freedom of Expression}

A huge furore arose in South Africa in 2012 over a painting entitled The Spear by artist Brett Murray. The painting depicted President Jacob Zuma as a Lenin figure but with his penis sticking out of his pants. It hung in an art gallery in the suburb of Rosebank, in Johannesburg. A Sunday newspaper, the City Press, put up the image on its website. It created rough and emotional public debate. The ANC found it abhorrent and offensive to the president's dignity (the Constitution declares that every individual in the country has a right to dignity). The ANC organized a protest march to the gallery with thousands of outraged supporters. The ruling party ordered City Press and the art gallery to remove the image from its website and the painting from the gallery.

\footnotetext{
${ }^{6}$ African National Congress (ANC) (2013).The Battle for Ideas. Communications and the Battle for Ideas: 53rd National Conference. Mangaung, December 2012. http://www.anc.org.za/docs/res/2013/resolutions53r.pdf

7 ibid.
} 
Citing freedom of expression and creative freedom, initially both the newspaper editor, Ferial Haffajee, ${ }^{8}$ and gallery owner, Lisa Esser, refused to succumb. The issue caused a huge chasm in society (Daniels, 2012) ${ }^{9}$ with many fights and contestations between those who felt this were a freedom of expression issue (allowed in the Constitution) and others who felt that Zuma deserved more respect for his dignity (also allowed in the Constitution). The image was then defaced by two visitors to the gallery and was then removed. Haffajee then capitulated and removed the image from the website saying she felt threatened and intimidated. ${ }^{10}$ The ANC's national spokesperson Jackson Mthembu's ringing call: "Don't buy City Press don't buy" became a signifier of political intimidation for the media on one side, and the ruling party's frustrations with the print media on the other.

A media rights lawyer, Dario Milo (also lawyer for Goodman Gallery and Brett Murray), attached significant political import to the incident vis-à-vis freedom of expression when he reflected:

The saga around The Spear illustrated to me one of the worst forms of abuse of freedom of artistic and political expression one can contemplate in a democracy and that is sheer intimidation and bullying by the ruling party to achieve a result which suited its agenda.There is no doubt in my mind that the Goodman Gallery and Brett Murray, whom I represented, would have won the case in the courts: the artwork was clearly protected under the defence of honest comment. $^{11}$

\section{Analysis: Closure on Dissent or Freedom of Expression}

As argued here, different views should be accepted in a democracy as legitimate adversaries rather than enemies, but the furore over The Spear showed exactly the opposite. City Press and its editor were treated as the "enemy". The political intimidation and bullying and the resulting capitulation attested to this. This was an indication of spaces in a democracy closing rather than the potential for gate-opening by journalists, and for a "democracy to come", suggested by Derrida. The question remains: How far could the editor and newspaper have gone and what would have happened if she had persisted and not removed the painting from City Press's website? There is no knowing for sure, but what we do know is the following: the political intimidation halted the process of a democracy that was unfolding and the Derridean "democracy to come" was abruptly stopped. The "harmony" and "justice" that the ANC thought it had achieved through a protest march over a painting was a false one, as it left many feeling extremely uncomfortable. There was no resolution to the issue: Where did freedom of expression sit in relation to harm to dignity? Where both clauses exist in the Constitution? It could have been tested in court if it was allowed to play itself out, but political intimidation put an end to the noise of the democracy.

Thus far, this article has painted a broad picture of the media landscape vis-à-vis the regulatory environment of 2012-2013. It has also highlighted some key issues, such as the closures in a democracy if the impending Secrecy Bill is passed, the restrictive nature of the National Key Points Act (with regard to what journalists can and cannot report) and the MAT resolution of the ruling party, which, while not implemented, remains as a scary threat to a free and independent media. In addition, it showed how robust debate and

\footnotetext{
${ }^{8}$ In 2014 Haffajee won the International Press Freedom award for courageous journalism from the Committee to Protect Journalists.

9 The Sunday Independent (2012), Getting some perspective on the spear, 27 May, 2012; Saturday Star (2012), It's staying up, 19 May, 2012; Sunday Times (2012), Presidential privates expose uncomfortable issues for ANC, 20 May 2012; and City Press (2012), Spear Divides ANC, 27 May, 2012.

10 ibid.

11 Milo, D. (2013). Email interview: 12 June, 2013.
} 
contestations during the time of a provocative painting of the president was shut down. The bill, the law, the resolution, and the closure of freedom of expression over a painting signified the aporias for media freedom - freedom of expression and the free flow of information in South Africa 2012-2013 in the build-up to the 20-year democracy celebrations of 2014.

The article now turns to two more incidents in 2013-2014 and extracts two big events from the State of the Newsroom (SoN) South Africa, 2014-Disruptions Accelerated (Wits Journalism, 2014) - to argue that the trend of closures is possibly accelerating.

\section{Arson in 2013 and Death of a Photographer in 2014}

In September 2013, a community radio station, Karabo FM, in the small town of Sasolburg in the province of the Free State, was burnt down to the ground in a blatant arson attack. ${ }^{12}$ Two armed men stormed into the building and ordered a radio presenter, his two studio guests and a female security guard out of the building into a nearby shed before sprinkling petrol in and around the station and setting it on fire. The attackers did not say why they were destroying the station and no one claimed responsibility, according to SoN.

Karabo board chairperson, Sam Mkwanazi, reported: "The whole building was destroyed. Our hard work of five years was destroyed in two minutes." This was the first attack, resulting in the destruction of a media outlet, since 1994. It did not receive much attention in the mainstream media and with the help of Professor Franz Krüger, the head of Wits Journalism Radio Academy, Karabo FM slowly started to rebuild the station. Researcher Jayshree Pather, writing a chapter in the SoN, entitled "Community Radio: Power Plays and Pressures", argued that the biggest pressure on Karabo FM was "political".

These political pressures, she wrote, took a number of different forms, including groups from political parties or factions (between 6-15 people) coming to the station and threatening presenters.

One staff member reported: "They say 'we come in peace, we want to address this issue'. If you want to guide them on how to raise their issues, they don't want to hear. They insist that they want to do this and if you stop them, then you are on the side of their enemies". As the station manager put it: "Politics got raised and the station got burned".

“On Saturday, 7 September 2013, two guys came in wearing balaclavas and with guns", a staff member told SoN. "There were two guests in the studio with the presenter. The armed men took the guests to the back door, tied up the security guard and came back to the studio. They asked the presenter to please switch off the mics and told him, 'We are here to do our jobs; we are not here to hurt you'. They then poured petrol and set the station alight".

Staff attributed the attack to the changing political landscape, increasing unhappiness in the community about the municipality's delivery of services and allegations of corruption involving the mayor, who was charged with arson after the attack along with the deputy ANC provincial chair of the area. The mayor was later given R5,000 bail and the court referred the matter back to the police for further investigation.

“(On) 1 January 2013 ... there was massive flooding in Zamdela and houses were blown away by the wind”, a staff member told Pather. "Anger started that the municipality was not doing enough. Then the demarcation issue surfaced. The community found out that the demarcation application had been processed and finalised. The community was unhappy and angered by the lack of consultation and residents began demanding that the newly appointed mayor step down".

The protests that erupted in Zamdela and Sasolburg left four people dead and 200 people were arrested. Residents were opposed to the merger because they said that the municipality was affected by "rampant

\footnotetext{
12 https://www.cpj.org/2013/09/south-african-community-radio-station-silenced-by.php
} 
corruption, poor service delivery, theft, nepotism and political interference", ${ }^{13}$ but mostly because of the lack of consultation over the proposal, Pather explained.

\section{Analysis: Foreclosures: Literally Burning down Voice}

In the theory of Mouffe and Derrida, Karabo FM signified voice, diversity, plurality, and agonistic difference in a small community. The voices from community members on the radio appeared to be at odds with the ruling political party, which was hegemonic and becoming increasingly insecure about its own failures to consult about changes to the community's boundary. Anger was being expressed at the lack of consultation about demarcation of municipal boundaries. This anger is part of a participative democracy, full of noise and robust fights and contestations. However, the radio station experienced the ultimate shut-down of dissension when it was burnt to the ground. By the end of 2014, the station was up and running again, after a significant struggle for resources, both in terms of equipment that it had lost and records of the radio station, financial and other. At this point in the article, it is worth moving right out of the country and put this incident in a worldwide media freedom context: South Africa's attacks on journalists appear to be part of a worldwide trend if one considers the research of the Committee to Protect Journalists (CPJ).

There was a high number of incidents of violence against journalists, particularly photographers, in South Africa in 2013-2014, and according to the CPJ, this number is growing around the world.

Worldwide in 2013-2014, more than half of those attacked were photographers and camera operators, according to the CPJ's research, which also showed that the deadliest places for journalists were in countries with large-scale civil unrest: Syria, Iraq, and Egypt. The organization's latest data in 2014 showed that there were 211 journalists imprisoned around the world, with Eritrea being the biggest jailor of journalists.

Journalists in South Africa in 2014 were not in danger to the same extent, there are, for instance, no journalists in jail. However, as discussed so far, there were worrying trends developing. In the past year in South Africa, photojournalists have been targeted most often when covering demonstrations by the police and sometimes by protestors. The CPJ's Africa programme director, Sue Valentine, observed: "They are targeted because of the power of images - photographs can provide incontrovertible proof of events. Anyone with a camera in their cellphone can be a target of police hostility as we have already seen this year". ${ }^{14}$ There appears to be little evidence that police are adequately trained to understand the role of the media. In South Africa, a pattern has emerged of police and VIP protection units becoming violent towards journalists, ostensibly to protect national state security interests. Another emerging trend is that members of the media are being attacked while covering service-delivery protests.

\section{The Ultimate Closure of Voice in a Democracy: Shot Dead for Taking Pictures}

In January 2014, police shot dead the 62-year-old freelance photographer-journalist and community activist, Michael Tshele, during a service-delivery protest in Mothutlung, Britz, in the North West Province (Daniels, 2014). The protest was over a water stoppage. Bystanders said Tshele was taking pictures of broken water pipes (the reason why there was no water in the township) when he was shot. Louise Vale, head of the Association for Independent Publishers, told SoN $2014^{15}$ that Tshele did work for community newspapers, the

\footnotetext{
13 http://mg.co.za/article/2013-01-25-00-shifting-borders-at-election-time

14 Valentine, S. (2014), Email comment on press freedom situation in SA: 24 February.

15 Vale, L. (2014), Email interview: 12 May.
} 
Kormorant and Leseding News, neither of which had details of his death. This attests to the vulnerable status of freelancers, both in South Africa and worldwide. There are two versions of the shooting: (1) Community members witnessed that Tshele was shot by a police officer because he had a camera and was taking photographs of broken water pipes; and (2) official sources felt he was probably a victim of the crossfire between protestors and police. City Press reported that Tshele was shot "in cold blood" because he had a camera in his hands. Tshele was well known by other community activists in the area, according to the newspaper report. ${ }^{16}$ "He only had a camera," community activist Solly Setlale said. "There was no stone in his hand. The only threat he posed was that his camera was recording evidence of what the police were doing".

The policeman allegedly took his gun, aimed and shot at Tshele, according to residents of the area who recognised the policeman. The day after Tshele's death, community activists spotted the policeman inspecting the area in a walk-about with the police commissioner. Police responded to the allegations thus: They noted the City Press report [by investigative journalist Jacques Pauw]; regretted the loss of life but "let us allow Ipid [Independent Police Investigative Directorate] to do their work... We can't deal with senseless rumor mongering," the North West police station said. Sanef said in a statement: "It would be a great shame and an embarrassment to South Africa's democracy if Tshele was indeed killed for taking pictures of a protest by poor citizens of this country". By mid-2014 no official report on the investigation had been released.

\section{Conclusion}

The author argues here that the ultimate act in shutting down of voice would be a killing. In this case, a photographer was killed. It is said that a picture tells a thousand words: The photographer was shot down while taking pictures of broken water pipes, signifying failure of delivery to the poor of a basic service-water. The ANC did not want people to know about its own failure, and so the state - the police - took it upon itself to shoot. In the theory of Mouffe's radical democracy, voices, dissent, fights, and contestations and noises are an essential intrinsic component of democracy.

In the theory of Derrida's "democracy to come", democracy can never be fully realized-it is always becoming. However, it can never have a chance of "becoming" or of going anywhere, let alone deepening, if there are as many foreclosures such as we have seen recently in the South African media freedom landscape: the impending Secrecy Bill, the National Key Points Act, the shutting down of freedom of expression during the Zuma penis painting; the MAT which would probably make journalists accountable to Parliament and finally, the arson attack and the shooting dead of a photographer.

These deliberately selected explications or "case studies" have been used to reach theoretical conclusions about the media freedom landscape, democracy's aporias and closures in South Africa's 20-year-old democracy. This is a young democracy in transition, but one in which the deepening of democracy is constantly halted or impeded, as strongly indicated in the evidence provided in this article.

The space of democracy is symbolically occupied by both the ANC and the media. Unfortunately, the media is recognised a symbolic outsider, an enemy and not a friendly or legitimate adversary within the unfolding democracy. With enemies there are no common symbolic spaces. Yet in South Africa, people cannot say that the media are enemies to a democracy - quite the reverse - they try to keep information flowing and they try to be gate-openers.

${ }^{16}$ City Press (2014), Marikana cops in Brits shoot out: 19 January. 
Closure of voice results in the homogenisation of society and requires unity of the media and the ruling party. This contradicts the theories of radical democracy. The unity of the media and the ruling party is not good news for an unrealized Derridean democracy. But the "yet to come" Derridean democracy cannot happen on the current trajectory (the Secrecy Bill, the threat of the MAT, the shutdown of dissent during the painting of the president, the arson attack and the ultimate closure - the death of a photographer).

Ultimately, if the free flow of the media is impeded, both the public and democracy suffer. It could then never be a deep and radical democracy. Johannsen, quoted at the beginning of this chapter, observed: "Secrecy obstructs democracy by keeping the public ignorant of information" and importantly, the role of the media should be to contribute to the creation of agonistic public spaces in which there is the possibility for dissensus to be expressed or alternatives to be put forward, as theorised by Mouffe. The media cannot contribute towards this radical democracy project if these closures persist.

\section{References}

African National Congress (ANC). (2010). Media, transformation, ownership and diversity. Retrieved from http://www.anc.org.za/ancdocs/ngcouncil/2010/media/pdf

Berger, G. (2002). Theorising the media democracy relationship in Southern Africa. International Communication Gazette, 64(1), 21-45.

Daniels, G. (2012). Fight for democracy: The ANC and the media in South Africa. Johannesburg: Wits Press.

Daniels, G. (2014). State of the newsroom, South Africa, 2014: Disruptions accelerated. Johannesburg: Wits Journalism.

Derrida, J. (2004). The last of the rogue states: The democracy to come. The South Atlantic Quarterly, 103(2/3), 323-341.

Freedom of Expression Institute (FXI). (2008). Themedia and the law: A handbook for community journalists. Johannesburg: Freedom of Expression Institute.

Jacobs, S. (2001). How good is the South African media for democracy? Mapping the South African public sphere after apartheid. Paper written during a fellowship at the Transregional Centre for Democratic Studies at the New School for Social Research, New York, pp. 49-56.

Johannsen, R. C. (1994). Military policies and the state system. In D. Held (Ed.), Prospectsfordemocracy: North south, east, west. Cambridge: Polity Press.

Laclau, E., \& Mouffe, C. (Eds.). (2001). Hegemony and socialist strategy: Towards a radical democratic politics. London: Verso. Lardner, T. (1993). Democratization and forces in African media. Journal of International Affairs, 47(1), 89-93.

Little, A., \& Lloyd, M. (2009). The politics of radical democracy. Edinburgh: Edinburgh University Press.

Mouffe, C. (1999). The challenge of Carl Schmitt: The essence of politics is struggle. London: Verso.

Mouffe, C. (2000). The democratic paradox. London: Verso.

Mouffe, C. (2005). The return of the political. London: Verso.

Mouffe, C. (2006). On the political: Thinking in action. London: Routledge.

Pather, J. (2014). Chapter community radio: Powerplays and pressures. In G. Daniels (Ed.), State of the newsroom, South Africa 2014: Disruptions' accelerated. Johannesburg: Wits Journalism. 